УдК 340

ББК 67

П 68

Ответственные редакторы:

B. M. Сырых, зав. отделом теории и истории права и судебной власти Российской академии правосудия, д-р юрид. наук, профессор, заслуженный деятель науки РФ

B. Н. Власенко, ст. науч. сотрудник отдела теории и истории права и судебной власти Российской академии правосудия, канд. юрид. наук

П 68 Правовое государство и правосудие: проблемы теории и практики / Отв. ред. В.М. Сырых, В.Н. Власенко. - М.: ЦКБ «Бибком»; РАП, 2014. - 660 с.

\title{
ISBN-online 978-5-905563-32-4
}

Настоящий сборник включает статьи и доклады ведущих российских ученых-правоведов, которые прозвучали на международной научно-практической конференции (РАП, Москва, 1519 апреля 2013 г.).

Сборник посвящен теоретическим и практическим проблемам совершенствования и повышения эффективности правоприменительной деятельности судов в условиях правового государства.

Издание может быть рекомендовано юридической общественности, аспирантам и студентам юридических вузов, а также практическим работникам.

ISBN 978-5-93916-416-0

ISBN-online 978-5-905563-32-4 (c) Коллектив авторов, 2014

(C) Российская академия правосудия, 2014

(c) ЦКБ «Бибком», оформление, 2014 


\section{Содержание}

\section{РАЗДЕЛ І \\ Общие теоретические и методологические проблемы правового государства и правосудия}

Ершов В.В. Правосудие в правовом государстве ……………………... 9

Лазарев В.В. Диссеминация науки в Конституционном Суде РФ .... 14 Лисюткин А.Б. Методологические аспекты исследования

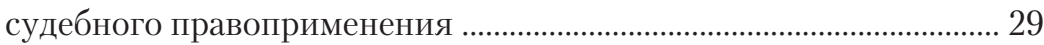

Матвеева Т.Д. Применение договорных норм международного права в судебной практике стран мира ………………………………... 38

Морозова Л.А. Правовые приоритеты ................................................... 49 Баранова М.В. Роль постановлений высших органов судебной власти Российской Федерации в правовой регламентации сферы рекламного бизнеса

Нематов А.Р. Участие высших судебных органов в правотворческой деятельности и формировании правового государства в Республике Таджикистан

Реутов В.П. Судебная практика и юридическая наука:

взаимодействие в процессе развития законодательства

Сапун B.A. Право и правосудие в правовом государстве:

проблемы соотношения и взаимодействия

Шафиров В.М. Правопонимание, правосудие, правосознание судей в правовом государстве 88

Трофимов В. В. Правосудие в системе юрисдикционных форм защиты субъективных прав и гарантий правового государства .. 101 Капииын В. М. Не-право в правовом государстве 112

\section{РАЗДЕЛ II \\ Конституционное правосудие в условиях правового государства}

Власова Г.Б. Проблемы развития конституционного правосудия в субъектах РФ (на примере субъектов Юга России) 
Зинков Е.Г. Функции судебной системы в условиях формирования

правового государства и его правового пространства

Кальяк А.М. Конституционный суд как институт

демократического государства

Ерыгина В.И., Ерыгин Я.А. Судебная защита прав и деловой

репутации политической партии

Макариев А.А. Деятельность судебных органов в сфере обеспечения эффективности норм избирательного права

Хорошильцев А.И. Власть Конституционного Суда Российской

Федерации и его место в системе органов государства 178

\section{РАЗДЕЛ III \\ Философские основы правосудия}

Смирнова М. Г. Социальные притязания в правовом государстве ... 186 Михайлов А.Е. Пределы деятельности суда в условиях правового государства: теоретико-методологический аспект .... 193 Кузьмин В.П. Правопонимание и судебная система в России: декларации и реальность

Мурунова А.В. Православно-правовые идеалы российского правосудия 216

Соломко 3.В. Критика концепта правления права

и идеологической роли судьи в современной западной

критической теории права

Черкашин B.A. Теоретические и практические проблемы реализации принципа разумности при совершенствовании российского правосудия 231

\section{РАЗДЕЛ IV}

\section{Общие проблемы правового государства и правосудия}

Николаев А. М. Деятельность Венецианской комиссии Совета Европы и формирование правового государства в России ......... 243 Толстик B.A. Прагматический подход к решению проблемы правопонимания: от плюрализма к обеспечению соответствия содержания права его критерию 
Куницын А.C. Проблема соотношения права и силы

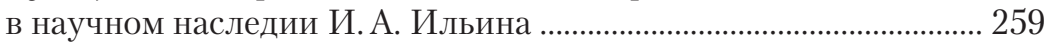
Дубровин Ю.Д. Что есть правовое государство? ............................... 267 Леусенко Д.А. Интегративное правопонимание, интегральная теория и генетический метод в юридической науке 276 Мартыненко Б.К. Правовое государство в современной России: миф или реальность? 282 Баранов А. В. Роль учредительных (декларативных) норм права в формировании правового сознания судей 292 Владимирова E.A. Исполнение решений ЕСПЧ органами государственной власти Российской Федерации .... 298 Краснова К.А., Кобеи П.Н. Специальные знания и основные формы их использования в современном судопроизводстве ..... 302 Утяшов Э.К. Правовые режимы и правовое государство: вопросы теории 309 Ярошенко Н.И. Система административных судов России: какой ей быть

\section{РАЗДЕЛ V}

\section{Проблемы повышения эффективности судебной деятельности и использования современных компьютерных технологий}

Давыдова М.Л. Демократизация как фактор совершенствования технологий правотворческой и правоприменительной деятельности 324

Чепунов О.И. К вопросу об эффективности российской судебной власти 329

Кобеи П.Н. О необходимости учета зарубежного опыта использования психологических методов активизации памяти участников судопроизводства в отечественной практике 339 Грьзунова Е.В. Судебное правоприменение законодательства об электронной подписи (практический аспект) 346 Гумеров Л.А. Научно-технический прогресс и судебная защита прав человека 356 Смирнов А. М. Самосуд как индикатор эффективности уголовного правосудия в условиях построения гражданского общества в России 
Ловиов Д.А., Мыззикков О.Н. Проблемы и задачи обеспечения легитимности судебной полиграфологической экспертизы в уголовном судопроизводстве

Курячая М.М. Внедрение элементов электронной демократии в судебную деятельность 381

Иншакова E.Г. Новые информационные технологии в системе правосудия: проблемы и перспективы применения

\section{РАЗДЕЛ VI Особенности правосудия как разновидности правоприменения}

Тузов Н.А. Критерии правосудия в правовом государстве 393 Догадайло Е.Ю. Правоприменение в условиях нестабильных форм права 399

Ковалева В.В. Тенденции современного правоприменения в условиях реформирования судебной системы России 410 Власенко В.Н. Юридическая квалификация как стадия правоприменительной деятельности

Землякова Г.Л. Некоторые проблемы правового регулирования кадастрового учета земельных участков в свете арбитражной практики 427 Гейт Н.А. Правовые основы реализации органами государственной власти региональной политики в сфере управления охраной окружающей среды и природопользованием

Болтанова Е.С. Пределы применения и вопросы правопонимания градостроительных норм о застроенных земельных участках 442

Cырых E.B. Применение некоторых принципов земельного законодательства при разрешении земельных споров 448

Чекмарева A.B. Тенденция упрощения судебных процедур на отдельных этапах гражданского судопроизводства 458 Шундиков К.В. Судебное и досудебное примирение как средство разрешения юридического конфликта: проблемы функционирования в современной России 465 Дулатова Н.В. Вопросы правоприменения судами норм о выселении собственников за бесхозяйственно содержимое жилое помещение .. 472 
Черникова Е. В., Николаева Т.А. Судебная защита права собственности в проекте изменений гражданского законодательства Российской Федерации 481

Князькова С. С. Практические проблемы применения судами законодательства о защите прав потребителей в сфере туристских услуг

\section{РАЗДЕЛ VII \\ Источники права и правосудия}

Anт Л. Ф. Место судебной практики в правовой системе Российской Федерации 496

Гук П.А. Нормотворческая функция высших судебных органов России 509

Шагиева Р.В., Ерофеева Д. В. Место актов судебной власти в системе источников частного права

Варламова Н.В. Разъяснения пленумов Верховного Суда РФ и Высшего Арбитражного Суда РФ по вопросам судебной практики в системе источников российского права

Иванов А.Б. Правовые позиции высших судов

как объект кодификации

Петрова Е.А. Юридическая природа судебного правотворчества в контексте принципа разделения властей (на примере США) ..... 546 Швещова М.В. К вопросу о юридической природе правовых позиций Европейского Суда по правам человека

Бабенко Н.А. Судебное право как комплексный элемент правовой системы

Шевиов А.Л. Теоретический анализ судебного прецедента как источника права Европейского союза и его роль в процессе правового регулирования общеевропейских интеграционных преобразований

\section{РАЗДЕЛ VIII История российского правосудия}

Золотухина Н.М. Первые проекты правовой организации Московского государства: Подкрестная (Крестоцеловальная) запись Василия Шуйского, Договоры с польским королем Сигизмундом III Августом и Приговор Первого Ополчения .... 579 
Арсанукаева М.С. Проблемы осуществления правосудия по делам горцев Северного Кавказа (XIX - начало XX вв.) ..... 587 Гайнутдинов Р.К. Предложения И. Т. Посошкова по совершенствованию судопроизводства в России 599

Кодан C.В. Судебная деятельность и формирование судебного права в России (XI - начало XX вв.) 606

Лысенков С.Г. Уголовное судопроизводство в годы

Великой Отечественной войны (1941-1945 гг.) 615 Дорская А.А. Роль мировых судов в развитии правосознания россиян во второй половине XIX - начале XX вв. (на примере мировых судов Санкт-Петербурга)

Жаров С.Н. Становление представлений о дуэли

как преступлении против правосудия в российском

праве XVIII-XIX вв.

Бородина Е.В. Особенности судопроизводства уездных

и дистриктных судов России в 1720-х гг. (на примере

судебной практики западных уездов Сибирской губернии) ....... 635

Филонова О.И. Модернизация судебной системы

в период НЭПа и защита интересов населения

Акишин М.О. Обычное право и юрисдикция

сибирских князей и родовых старейшин

в российском государстве (XVI - начало XX вв.) 644

Еремин С.Г. История возникновения и развития

законодательства об обязательном социальном страховании ... 653 